Article

\title{
Fuzzy Complex Proportional Assessment Applied in Location Selection for Installation of Photovoltaic Plants
}

\author{
Paulo Antônio Xavier Furtado *(1) and Antônio Vanderley Herrero Sola \\ Production Engineering Department, Federal University of Technology-Paraná (UTFPR), \\ Ponta Grossa 84016-210, Brazil; sola@utfpr.edu.br \\ * Correspondence: paulofurtado@alunos.utfpr.edu.br
}

Received: 6 November 2020; Accepted: 24 November 2020; Published: 27 November 2020

\begin{abstract}
This article proposes the application of a multi-criteria decision-making method based on fuzzy complex proportional assessment (COPRAS-F), applying business sustainability criteria, to rank alternative sites for the installation of photovoltaic plants, as selected from a geographic suitability index map of vast and heterogeneous regions in Southern Brazil, obtained from a geographic information system. As a key feature, the methodology serves the interests of stakeholders during decision-making meetings in a personalized manner, eliminating the need for consensus to overcome conflicts and antagonistic positions, allowing them to maintain a strictly professional view and to communicate in business language. The results indicate that the best location from a geographical viewpoint may not be the best location from a business viewpoint.
\end{abstract}

Keywords: COPRAS-F method; MCDM model; photovoltaic plant location; energy planning; renewable energy

\section{Introduction}

The increasing demand for electric power in a global economy, characterized by an alarming recession of global fossil fuel reserves, has imperatively induced a collapse in energy generation balance [1]. Therefore, generation expansion planning for renewable and unrenewable energy has been used to define the least costly capacity expansion plan to meet forecasted demand via a pre-defined reliability criterion and emission constraint through a long-term plan [2].

Photovoltaic energy stands out among renewable energy sources for being environmentally and socioeconomically beneficial, if its implementation takes place in appropriate locations through efficient planning and management [3]. It has generally been met with public acceptance.

Currently, making photovoltaic energy system projects more widely and swiftly feasible depends on adequate incentive policies or innovative business models that are capable of mitigating high initial costs, as well as lowering uncertainty regarding long-term financial return [3].

These factors add complexity to the high-risk decision-making processes of locating possible installation sites for photovoltaic plants, and of implementing models of geographic information systems (GIS), while applying geographic criteria and restrictions. In the face of such complexity, policymakers, specialists, and researchers in the field have proposed the use of models based on multi-criteria decision-making (MCDM) methods that include business-oriented criteria.

\section{Literature Review}

From the publications of "State of the Art", it is possible to notice that several articles, which focus on energy planning-applied GIS and SIG-MCDM methods with geographic subcriteria in the selection 
and rank of alternative sites for the location of photovoltaic power plants, feature weaknesses when not jointly applying business criteria.

By further analyzing these methods, attention is drawn to the conclusions of the following researches, which assessed photovoltaic energy projects:

- Tomosk et al. [4] demonstrated that only the use of geographical criteria for the location of photovoltaic plants is insufficient. The authors concluded that financial return rate maps differ substantially from solar irradiation maps in the United States. Thus, the prediction that climate is always directly related to the rate of return of a solar project is mistaken. The reason for that is because, in this case, the rate of economic return is directly related to the tax model and time of use;

- Vafaeipour et al. [5] stated, "that in contrast to common assumptions, the identification of suitable geographical locations for the implementation of large photovoltaic plants is not only related to the amount of solar radiation received, but there are also many other economic, environmental, social, and risk factors that must be taken into account".

Changes are necessary to overcome these deficiencies in the GIS and SIG-MCDM decision-making methods, which only take into account the geographic subcriteria. The proposed solution is the application of MCDM methods with business subcriteria to rank the alternatives of sites as selected by the geographic suitability index, allowing the use of the investors' everyday business language in choosing between more geographically compatible locations for photovoltaic plant installation.

There has been an evolutionary process in the lines of research involving decision making in renewable energy projects. This process began with the application of overlay operations in geographic information systems (GIS) of geographic subcriteria fuzzified maps (climate, geomorphology, location, and land use), with the elimination of geographical restrictions, so that a geographic suitability index map of alternative areas for the installation of renewable energy plants (Figure 1) could be generated.

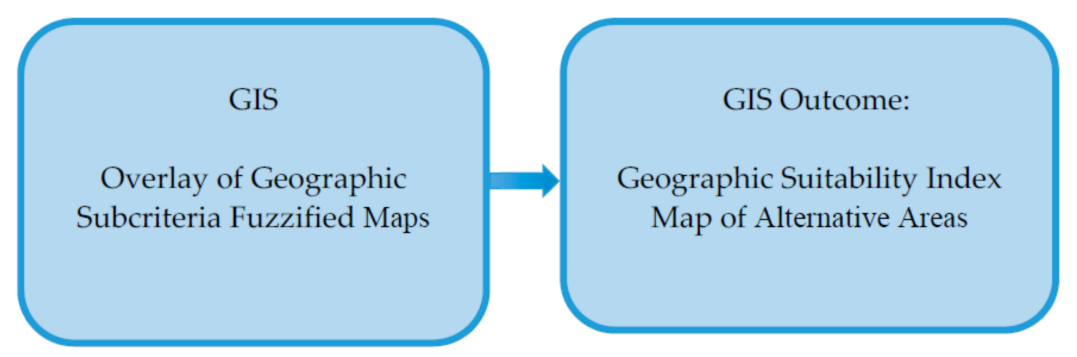

Figure 1. Geographic information systems (GIS) methodology.

The works listed below (Table 1) stand among those focusing on photovoltaic plants:

Table 1. GIS.

\begin{tabular}{|c|c|}
\hline Authors & Results \\
\hline Brewer et al. [6] & $\begin{array}{l}\text { Generated maps of the solar energy potential of southwestern USA, including social } \\
\text { acceptance data. }\end{array}$ \\
\hline Janke [7] & $\begin{array}{l}\text { Identified } 191 \mathrm{~km}^{2} \text { of highly suitable areas for solar farms in Northwest Colorado, } \\
\text { in the USA. }\end{array}$ \\
\hline Sabo et al. [8] & Identified $10,092.08 \mathrm{~km}^{2}$ for the installation of large photovoltaic plants in Malaysia. \\
\hline Wang et al. [9] & $\begin{array}{l}\text { Applied GIS to select } 4005 \text { sites suitable for photovoltaic energy projects, with the } \\
\text { majority in the Shigatse and Ngari regions in Tibet, China. }\end{array}$ \\
\hline Maleki et al. [10] & $\begin{array}{l}\text { Applied GIS to assess the size and location of rural areas for photovoltaic projects, } \\
\text { considering energy quality and cost for the Birjand region in Iran. }\end{array}$ \\
\hline
\end{tabular}


Another concomitant research has introduced the GIS-MCDM method by applying weighted linear combination (WLC) or ordered weighted average (OWA) when adding fuzzy maps of geographic subcriteria during the GIS overlap process (Figure 2) to identify alternative photovoltaic plant locations.

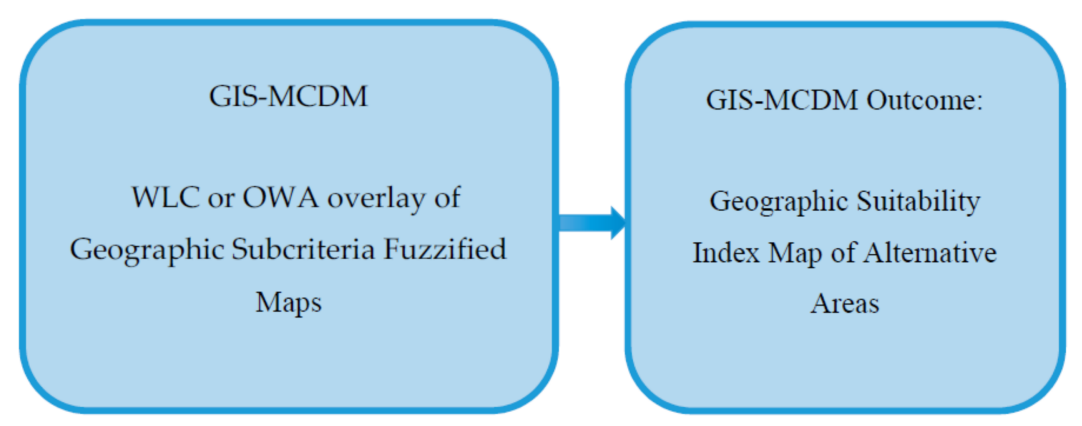

Figure 2. GIS-multi-criteria decision-making (MCDM) methodology.

The works listed below (Table 2) stand among those focusing on photovoltaic plants:

Table 2. Typical GIS-MCDM.

\begin{tabular}{ll}
\hline \multicolumn{1}{c}{ Authors } & \multicolumn{1}{c}{ Methods and Results } \\
$\begin{array}{l}\text { Charabi and } \\
\text { Gastli [1] }\end{array}$ & $\begin{array}{l}\text { Applied the MCDM ordered weighted average fuzzy (FLOWA) to define weights used in } \\
\text { GIS when generating a map of Oman that showed high suitability for the installation of } \\
\text { large photovoltaic plants in 0.5\% of the country's area }\end{array}$ \\
\hline $\begin{array}{l}\text { Al Garni and } \\
\text { Awasthi [12] }\end{array}$ & $\begin{array}{l}\text { Applied the MCDM analytic hierarchy process (AHP) to define weights used in } \\
\text { GIS-MCDM (WLC) when generating a suitability map of Saudi Arabia that showed that } \\
\text { 16\% of the country is suitable for installing small-scale photovoltaic plants }\end{array}$ \\
\hline $\begin{array}{l}\text { Aydin et al. } \\
\text { [13] }\end{array}$ & $\begin{array}{l}\text { Applied GIS-MCDM (OWA) to generate maps of global performance indexes for } \\
\text { environmental objectives and economic viability, indicating the provinces of Aydin, Usak, } \\
\text { Burdur, Denizli, and Mugla in Turkey as priorities for photovoltaic energy sites. }\end{array}$ \\
\hline $\begin{array}{l}\text { Wanderer and } \\
\text { Herle [14] }\end{array}$ & $\begin{array}{l}\text { Applied MCDM (AHP) to define the weights used in GIS-MCDM (WLC and OWA) } \\
\text { methods, generating a map of suitability for Andalusia, in Spain, regarding solar energy, } \\
\text { presenting more sites that are suitable-located in the Guadalquivir Valley. }\end{array}$ \\
\hline $\begin{array}{l}\text { Watson et al. } \\
\text { [15] }\end{array}$ & $\begin{array}{l}\text { Applied GIS-MCDM (AHP) to generate a map of the south of England, which showed an } \\
\text { added 345 km }{ }^{2} \text { of suitable areas. }\end{array}$ \\
\hline $\begin{array}{l}\text { Merrouni et al. } \\
\text { [16] }\end{array}$ & $\begin{array}{l}\text { Applied MCDM (AHP) to define the weights used to aggregate the suitability index of } \\
\text { categorized subcriteria maps, when determining that eastern Morocco is highly suitable, } \\
\text { with 19\% of the land proven as appropriate for the installation of large photovoltaic plants. }\end{array}$ \\
\hline
\end{tabular}

The same period also showed the increased application of MCDM methods with technical-economic and socio-environmental business criteria (Figure 3), more specifically in energy planning.

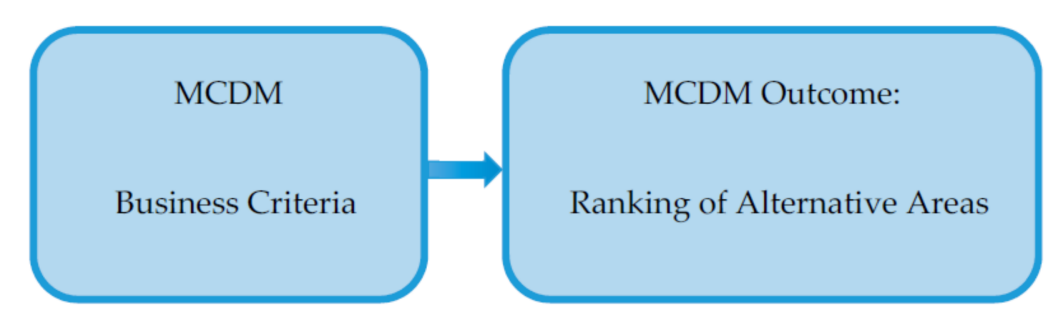

Figure 3. Current MCDM methodology.

The following (Table 3) are highlights among these works: 
Table 3. MCDM.

\begin{tabular}{ll}
\hline \multicolumn{1}{c}{ Authors } & \multicolumn{1}{c}{ Methods and Results } \\
\hline $\begin{array}{l}\text { Mourmouris } \\
\text { and Potolias [17] }\end{array}$ & $\begin{array}{l}\text { Applied the REGIME method with business criteria to classify renewable energy systems } \\
\text { based on energy efficiency for installation on the island of Thassos, in Greece }\end{array}$ \\
\hline Vafaeipour [5] & $\begin{array}{l}\text { Applied step-wise weight assessment ratio analysis-weighted aggregates sum product } \\
\text { assessment (SWARA-WASPAS) with business criteria in prioritizing city alternatives for } \\
\text { photovoltaic plant location in Iran }\end{array}$ \\
\hline Wang et al. [18] & $\begin{array}{l}\text { Applied MCDM methods fuzzy analytic hierarchy process-technique for order of } \\
\text { preference by similarity to ideal solution (FAHP-TOPSIS) to rank locations for the } \\
\text { construction of a solar power plant in Vietnam. }\end{array}$ \\
\hline Barin et al. [19] & $\begin{array}{l}\text { Applied a novel fuzzy-based expert system with business criteria for selecting renewable } \\
\text { energy technologies, along with technical-economic and environmental criteria in Brazil. }\end{array}$ \\
\hline $\begin{array}{l}\text { Karasan et al. } \\
\text { [20] }\end{array}$ & $\begin{array}{l}\text { Applied the combinative distance based assessment (CODAS) method, crisp and ordinary } \\
\text { fuzzy CODAS methods, with business criteria to select sites for the construction of a wind } \\
\text { farm in Turkey. }\end{array}$ \\
\hline $\begin{array}{l}\text { Samanlioglu } \\
\text { and Ayag [21] }\end{array}$ & $\begin{array}{l}\text { Applied MCDM Fuzzy AHP (F-AHP) and fuzzy preference ranking organization method } \\
\text { enrichment evaluation (F-PROMETHEE) methods to evaluate alternative solar plant } \\
\text { locations in Turkey. }\end{array}$ \\
\hline
\end{tabular}

It has been observed that the GIS and GIS-MCDM methods that apply geographic subcriteria, and MCDM that apply business subcriteria, are complementary, because:

- The GIS and GIS-MCDM methods present strengths when selecting and classifying alternative areas from a geographic point of view, but they present weaknesses when technical-economic and socio-environmental characteristics are not considered;

- The MCDM methods present strengths when selecting and classifying alternative areas from a business point of view, but they present weaknesses when climatic, geomorphological, location and land use characteristics are not considered.

In order to eliminate the weaknesses of the previous methods, this article suggests the following model (Figure 4) for the selection and classification of alternative sites for the installation of photovoltaic plants in vast areas of land, generally characterized by their great heterogeneity of the climate, geomorphology, location, land use, technical-economic, and socio-environmental conditions:

- Selection of alternative sites from a geographic suitability index map developed in current GIS-MCDM from geographic subcriteria;

- Application of the MCDM method based in business criteria to rank specific alternatives of sites for the installation of photovoltaic plants.

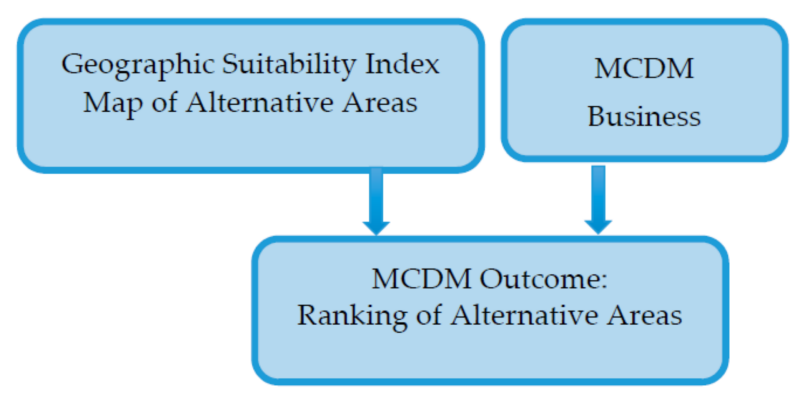

Figure 4. MCDM methodology proposed.

\section{The Model}

The model proposed in this article was developed from the identification and description of the following elements: 
- The problem: consists in the selection and classification of alternatives of suitable areas for the installation of photovoltaic plants, localized in different regions of a large territory, presenting climatic, geomorphological, location, land use, economic, social, and environmental heterogeneities;

- The alternatives: are selected from the geographic suitability index map of the area under evaluation, obtained by overlaying fuzzified geographical subcriteria maps;

- The stakeholders: the choice of stakeholders must take into account the complexity of the decision-making process and must come from different groups of stakeholders with different scenarios of interests, such as public and private investors, different spheres of public administration, environmentalists, and communities;

- The business criteria and subcriteria: stakeholders are responsible for evaluating, based on the literature, which economic, technical and environmental criteria of the business with their respective subcriteria are in the interest of business, considering the availability of public or private databases, for research on the values of the business subcriteria;

- The MCDM method: the application of MCDM methods using business criteria is widely used in energy planning [22]. Among other advantages, it allows stakeholders to reach an agreement based on the evaluation of numerous conflicting criteria from multiple dimensions. In the decision-making process for locating decentralized energy projects, typical for several renewable energies, some factors significantly influence the choice of the multi-criteria method:

$>$ The context of the decision-making process of companies investing in the energy sector, in which there are usually multiple decision makers or investors, thus hindering the reaching of a consensus and leading decision makers to act more individually due to economic issues;

$>$ Uncertainty plays an important role in the project's decision-making problems that involve incomplete and imperfect information of real-world situations [23];

$>\quad$ Conflicts among decision makers and investors regarding the real importance of interests from multiple dimensions, represented in practice by those criteria with accompanying business-related subcriteria;

$>\quad$ The uncertainties surrounding the real values of the multiple interest dimensions regarding alternative sites for photovoltaic plants.

The choice of the MCDM method for the installation of photovoltaic plants in vast and large regions with geo-economic and socio-environmental heterogeneities must take into account all the aspects that were mentioned above.

\section{Model Application-Location Selection for Photovoltaic Plant in Vast and Heterogeneous Regions}

\subsection{Identification of the Problem}

The area under evaluation for selecting sites alternatives for installing photovoltaic plants spreads throughout $199,315 \mathrm{~km}^{2}$ in Southern Brazil (Figure 5). It consists of 10 mesoregions with a population (estimated by the Brazilian Institute of Geography and Statistics-IBGE) of 11,348,937 inhabitants distributed across 399 municipalities, 335 of which with populations under 30,000. The area comprises a large-scale energy distribution network, mostly with $34.5 / 13.8 \mathrm{kV}$ substations, representing an ideal framework for small-scale distribution of photovoltaic power generation.

\subsection{Identification of Alternative Sites Based on a Geographic Suitability Index Map}

The geographic suitability index map of the area under evaluation (Figure 5) was prepared in Quantum GIS (QGIS) by the Department of Cartographic Engineering of the Federal University of Paraná (UFPR). This was prepared through weighted aggregation, applying the MCDM weighted 
linear combination (WLC) in the overlay of geographic subcriteria suitability index maps, which were obtained from the fuzzification of the irradiation, temperature, land slope, land aspect, and distance from roads maps, with the subsequent elimination of crisp geographic restrictions of conservation units, land use and distance from cities and towns.

The geographic suitability index map of the area consists of pixels with degrees of fuzzy pertinence between 0 and 1 , classified into categories from unsuitable to most suitable (unsuitable $<0.188,0.1889$ $\leq$ low suitability $<0.376,0.3777 \leq$ moderate suitability $<0.584,0.585 \leq$ suitable $<0.752$, most suitable $\geq 0.753)$.

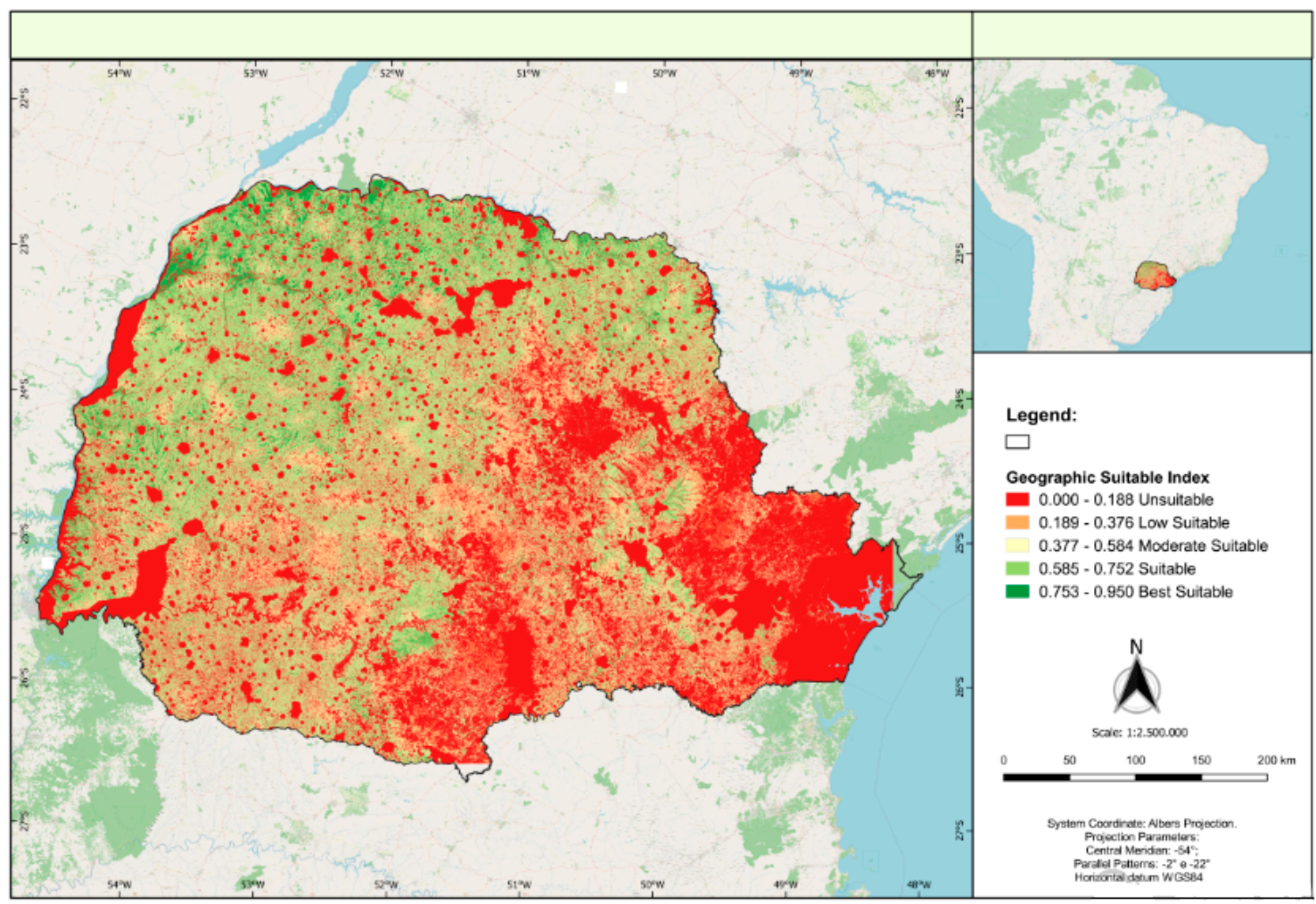

Figure 5. Geographic suitability index map.

The geographic suitability index map of the area under evaluation allowed the identification of the 10 alternative sites (Table 4) with the highest suitability indexes. These sites, however, presented different energy production capacities: across the 10 mesoregions, they were located next to paved roads assisted by 13.8 or $34.5 \mathrm{kV}$ electricity networks and with areas between $20,000 \mathrm{~m}^{2}$ and 100,000 $\mathrm{m}^{2}$, sufficient for small-scale photovoltaic generation from 1 to $5 \mathrm{MW}$.

Table 4. GIS ranking.

\begin{tabular}{ccccccccccc}
\hline Variables & \multicolumn{10}{c}{ Alternatives } \\
\hline & A1 & A2 & A3 & A4 & A5 & A6 & A7 & A8 & A9 & A10 \\
\hline Geographic Suitability Index & 0.91 & 0.85 & 0.86 & 0.75 & 0.95 & 0.94 & 0.93 & 0.9 & 0.83 & 0.89 \\
Ranking (GIS) & 4 & 8 & 7 & 10 & 1 & 2 & 3 & 5 & 9 & 6 \\
\hline
\end{tabular}

\subsection{Identification of Stakeholders}

The following group of 10 stakeholders with 20 to 35 years of experience was invited to participate in the surveys: 
- Two male and two female engineers from the superintendence of energy distribution of an energy utility, with technical-economic and socio-environmental experience and a point of view aligned with government and investor interests alike;

- Four managerial engineers from three multinational companies that supply the energy sector, with technical-economic experience and a point of view aligned with the interests of private supplier industries;

- A state social worker with a point of view aligned with the government's and society's interests alike;

- A chemical industry director engineer with technical administrative experience with a point of view aligned with environmental interests.

All of them accumulate strategic-level decision-making experience in large national and multinational companies with thousands of employees. The group is also experienced in state contracts and projects, mainly in the energy sector, representing the interests of the government, investors and society.

Considering the homogeneity of experience of the stakeholder group, the information collected in the surveys was treated with the same degree of importance.

\subsection{Identification of Criteria and Subcriteria}

The stakeholders agreed on the use of everyday business-related subcriteria drawn from the literature in the field and with the availability of information in public or private databases. After further evaluation of the business subcriteria by the stakeholders, the following were eliminated or replaced:

- The economic subcriteria of net present cost and cost-benefit were eliminated because they need extensive and complex economic feasibility studies for each site alternative, in addition to the limited availability of national public data for smaller projects involving photovoltaic plants;

- The technical subcriterion of net generation efficiency was eliminated for presenting calculations with inaccurate future forecasts. The annual availability factor was replaced by the duration of interruption per consumer unit (DEC), for having values for each alternative site in a public database;

- Technical subcriteria for reliability, maturity and safety of solar technology were eliminated due to the subcriterion Duration of interruption per consumer unit (DEC) having already encompassed failures of this type of power generation;

- Political and legal risk subcriteria were eliminated because it is a region with the same political and legal risks.

The subcriteria that were maintained were the ones that stemmed from literature and were available in a public access database of private or state source, or of simple calculation, mandatory for administrative daily use in the business (Table 5).

\subsection{Identification of the Multi-Criteria Decision-Making Method}

Taking into account, as previously mentioned, the interests and conflicts among stakeholders, also considering the insecurity and risks of investors in the energy sector, a qualitative and diffuse MCDM method was applied in this study. The method considers the importance and values of photovoltaic plant location criteria, regarding a compensatory nature in their internal aggregation procedure.

The option for the fuzzy complex proportional assessment (COPRAS-F) method relied on its easy application as well as its linguistic and diffuse nature, which facilitate the resolution of conflicts during the decision-making process. Furthermore, this method allows for good performance in some subcriteria to counterbalance poor performance in other subcriteria, and has been applied by many researchers in the last decade [23]. 
Table 5. Enterprise or business subcriteria.

\begin{tabular}{|c|c|c|}
\hline Criteria & Subcriteria & Literature \\
\hline \multirow{4}{*}{ Economic } & C1-Investment cost & $\begin{array}{l}\text { Beltrán et al. [24], Haddad et al. [25], Klein and Whalley [26], La Rovere } \\
\text { et al. [27], Mourmouris and Potolias [17], Stein [28], Tsoutsos et al. [29], } \\
\text { Wang JJ et al. [30]. }\end{array}$ \\
\hline & C2-Payback period & Haddad et al. [25], Wang JJ et al. [30]. \\
\hline & C3-Construction period & La Rovere et al. [26]. \\
\hline & $\begin{array}{l}\text { C4-Operation and maintenance } \\
\text { team cost }\end{array}$ & $\begin{array}{l}\text { Haddad et al. [25], Mourmouris and Potolias [17], Stein [28], Wang JJ et } \\
\text { al. [30], Zerpa e Yusta [22]. }\end{array}$ \\
\hline \multirow{3}{*}{ Technical } & C5-Eletricity generation potential & La Rovere et al. [26]. \\
\hline & C6-Capacity factor & $\begin{array}{l}\text { Haddad et al. [25], Klein and Whalley [26], Maxim [31], Stein [28], } \\
\text { Zerpa and Yusta [22]. }\end{array}$ \\
\hline & $\begin{array}{l}\text { C7-Duration of interruption per } \\
\text { consumer unit (DEC) }\end{array}$ & Grossmann et al. [32] (Intermittency of Power Supply). \\
\hline \multirow{2}{*}{ Environmental } & $\begin{array}{l}\mathrm{C} 8 \text {-Monthly } \mathrm{CO}_{2} \text { emission in } \\
\text { transport }\end{array}$ & $\begin{array}{l}\text { Castillo et al. [3]; Klein and Whalley [26], La Rovere et al. [27], } \\
\text { Mourmouris and Potolias [17], Onat and Bayar [33], Stein [28], Zerpa } \\
\text { and Yusta [22], Zhang et al. [34]. }\end{array}$ \\
\hline & $\begin{array}{l}\text { C9-Photovoltaic module disposal } \\
\text { (Service Life) }\end{array}$ & $\begin{array}{l}\text { Klein and Whalley [26], Mourmouris and Potolias [17], Wang JJ et al. } \\
\text { [30]. }\end{array}$ \\
\hline \multirow{3}{*}{ Social } & C10-Seasonal jobs numbers & Stein [28], Zerpa and Yusta [22], Wang JJ et al. [30], Zhang et al. [34]. \\
\hline & C11-Long-term jobs numbers & Stein [28], Zerpa and Yusta [22], Wang JJ et al. [30], Zhang et al. [34]. \\
\hline & C12-Benefited population & $\begin{array}{l}\text { Beltrán et al. [24], Klein and Whalley [26], La Rovere et al. [27], Maxim } \\
\text { [31], Mourmouris and Potolias [17], Wang JJ et al. [30], Zerpa and Yusta } \\
\text { [22], Zhang et al. [34]. }\end{array}$ \\
\hline
\end{tabular}

\subsection{Description of the Fuzzy Complex Proportional Assessment Method}

Zavadskas and Antucheviciene introduced COPRAS-F in 2007. It is one of the fuzzy multicriteria decision-making techniques used to determine the importance of each criterion and classify alternatives through linguistic terms associated with fuzzy membership functions [35-37]. The method presents the following characteristics:

- It allows benefit and cost criteria to be used in the decision matrix [38] and criteria values to be normalized so that different units of measure can be used and compared;

- It determines the best among a set of viable alternatives and the remaining alternatives as reasons for the best one, assuming direct and proportional dependence on the degrees of significance and utility of the alternatives in a criteria system [38];

- It uses fuzzy logic that can model the existing uncertainty by applying a linguistic variable associated with fuzzy numbers, identifying the degree of relevance in a closed range from 0 to 1 , which makes it a useful concept to deal with complex or not well-defined situations;

A fuzzy set is a powerful mathematical tool for handling the existing uncertain in decision making, and is a general form of a crisp set. A fuzzy number belongs to the closed interval 0 and 1 , in which 1 addresses full membership and 0 expresses non-membership; whereas, crisp sets only allow 0 or 1 [37].

To apply the MCDM COPRAS-F method, the model follows three steps, as shown in Figures 6, 8 and 9 respectively. In the first step, the decision fuzzy matrix (Figure 6) must be structured based on the choice of the fuzzy membership function, followed by the structuring of the linguistic terms of criteria to apply the fuzzy searches of criteria. 


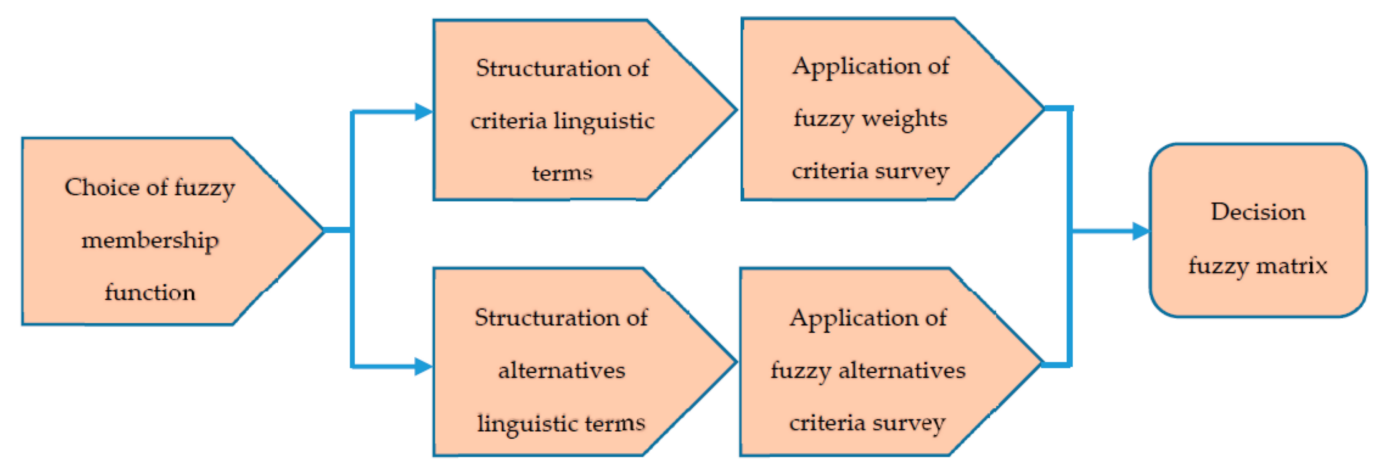

Figure 6. Decision fuzzy matrix.

Different fuzzy membership functions may be applied from the fuzzy modeling of the problem. An option was made for the application of fuzzy triangular membership functions (Figure 7) [37], which presents the advantages of facilitating the surveys with stakeholders, making it easier to implement and process information in a fuzzy environment than other fuzzy pertinent functions [37].

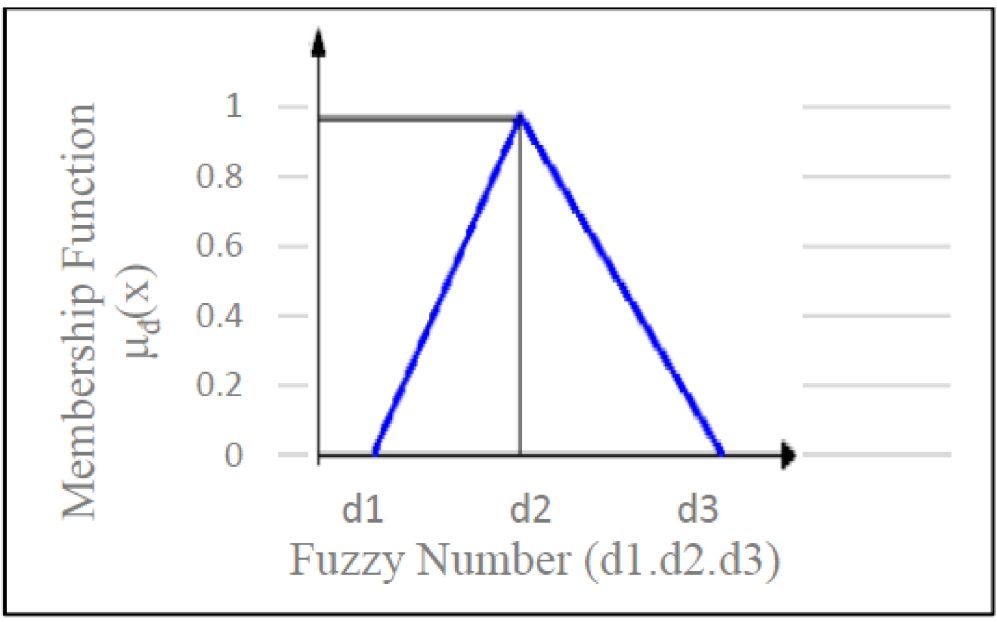

Figure 7. Fuzzy triangular membership function.

To represent the triangular membership function (Figure 6), the fuzzy numbers are taken spread left $d 1$, center $d 2$ and spread right $d 3$, being:

$$
\begin{array}{ll}
\mu_{x}(x)=0 \quad x\langle d 1 \text { or } x>d 3 \\
\mu_{x}(x)=(x-d 1) /(d 2-d 1) & d 1 \leq x \leq d 2 \\
\mu_{x}(x)=(x-d 3) /(d 2-d 3) & d 2 \leq x \leq d 3
\end{array}
$$

Chatterjee and Bose [35] described the COPRAS-F mathematical concept as follows:

- Choice of the linguistic labels for criteria and for alternatives (Table 6) [35]: both the importance of the criteria weights and the qualitative categorization of alternatives are collected through research along the stakeholders, using linguistic variables expressed in triangular fuzzy numbers. 
Table 6. Linguistic terms for criteria and alternatives.

\begin{tabular}{llll}
\hline $\begin{array}{c}\text { Linguistic Terms for } \\
\text { Criteria }\end{array}$ & \multicolumn{1}{c}{ Fuzzy Numbers } & \multicolumn{1}{c}{$\begin{array}{c}\text { Linguistic Terms for } \\
\text { Alternatives }\end{array}$} & Fuzzy Numbers \\
\hline Very High (VH) & $(0.9,1.0,1.0)$ & Very Good (VG) & $(0.9,1.0,1.0)$ \\
High (H) & $(0.7,0.9,1.0)$ & Good (G) & $(0.7,0.9,1.0)$ \\
Moderate High (MH) & $(0.5,0.7,0.9)$ & Medium Good (MG) & $(0.5,0.7,0.9)$ \\
Moderate (M) & $(0.3,0.5,0.7)$ & Medium (M) & $(0.3,0.5,0.7)$ \\
Moderate Low (ML) & $(0.1,0.3,0.5)$ & Medium Poor (MP) & $(0.1,0.3,0.5)$ \\
Low (L) & $(0.0,0.1,0.3)$ & Poor (P) & $(0.0,0.1,0.3)$ \\
Very Low (VL) & $(0.0,0.0,0.1)$ & Very Poor (VP) & $(0.0,0.0,0.1)$ \\
\hline
\end{tabular}

- Development of the fuzzy decision matrix: for each decision maker, a fuzzy number decision matrix will be obtained with $\mathrm{m}$ rows and $n$ columns, considering that the number of criteria is $n$ and the number of alternatives is $m$ :

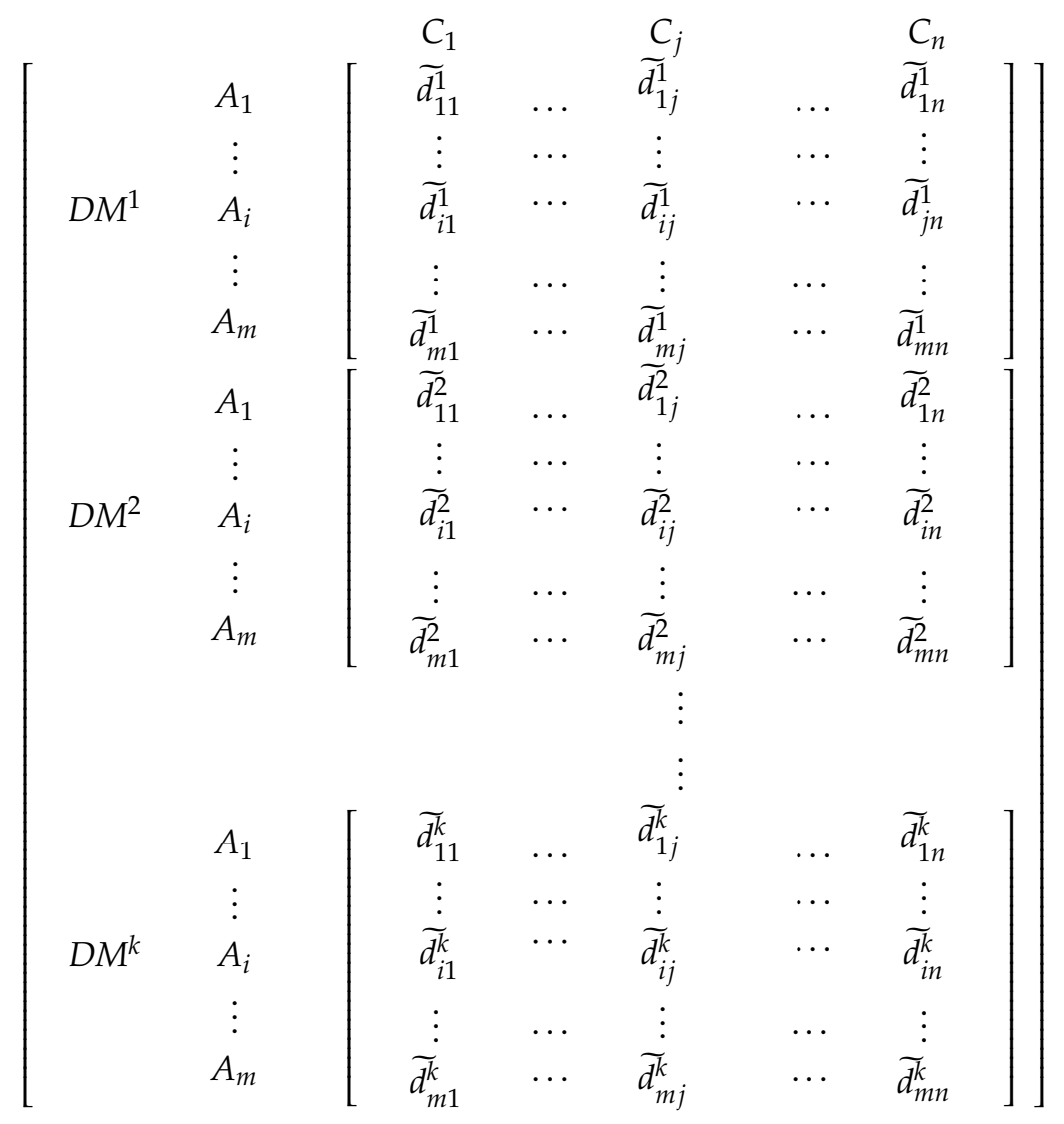

In such case:

- $\quad D M^{k}$ is the $k$ th decision maker

- $A_{m}$ is the $m$ th alternative

- $C_{n}$ is the $n$th criterion

$$
\widetilde{d}_{i j}^{k}=d_{i j 1}^{k} \cdot d_{i j 2}^{k} \cdot d_{i j 3}^{k}
$$

During the second step, after obtaining the fuzzy decision matrix, the weighted normalized defuzzied decision matrix (Figure 8) must be obtained through calculations of fuzzy (weights and alternatives) criteria average followed by the defuzzification process by the center of the area method with final normalization. 
- Subsequently, applying the fuzzy weighted averaging (FWA) operator, the responses from decision makers are aggregated $(\mathrm{Xu}$ and $\mathrm{Da}, 2003)$, considering $\widetilde{q}_{k}$ the diffuse significance coefficient of the $\mathrm{k}^{\text {th }}$ decision maker. If $\mathrm{k}$ is homogeneous, then $\widetilde{q}_{k}=(1 / k, 1 / k, 1 / k)$. Therefore, the aggregated fuzzy decision matrix using Equation (2) will be represented as follows:

$$
\widetilde{D}=\left[\widetilde{d}_{i j 1} \cdot \widetilde{d}_{i j 2} \cdot \widetilde{d}_{i j 3}\right]
$$

where:

$$
\widetilde{d}_{i j}=\frac{\sum_{k=1}^{k} \widetilde{q}_{k} \widetilde{d}_{i j}^{k}}{\sum_{k=1}^{k} \widetilde{q}_{k}}
$$

- Defuzzification: to defuzzify the fuzzy weight of each criterion into crisp values, the centre of area (COA) defuzzification method is applied. This method is simple and practical, with no need of including the preferences of any evaluator. The value of best non-fuzzy performance $(B N P)$ for the fuzzy number can be found by using the following equation for a triangular fuzzy function:

$$
B N P=\frac{\left[\left(d_{3}-d_{1}\right)+\left(d_{2}-d_{1}\right)\right]}{3}+d_{1}
$$

- Normalization of defuzzified decision-making matrix: the normalized values of this matrix are calculated by the equation:

$$
\bar{d}_{i j}=\frac{d_{i j}}{\sum_{i=1}^{m} d_{i j}}(1 \leq i \leq m, 1 \leq j \leq n)
$$

- Calculation of criteria weight: defuzzify the fuzzy weight of each criterion $\left(w_{1}, w_{2}, w_{3}\right)$ in crisp values $\left(w_{\mathrm{j}}\right)$ :

$$
w_{j}=\frac{\left[\left(w_{3}-w_{1}\right)+\left(w_{2}-w_{1}\right)\right]}{3}+w_{1}
$$

- Calculation of the weight of the $j^{\text {th }}$ criterion is depicted as follows:

$$
q_{j}=\frac{w_{j}}{\sum_{j=i}^{n} w_{j}}
$$

- Calculation of the weighted normalized fuzzified decision matrix: the weighted normalized fuzzified values are calculated by the equation:

$$
\hat{d}_{i j}=\bar{d}_{i j} x q_{j} \quad(1 \leq i \leq m, 1 \leq j \leq n)
$$

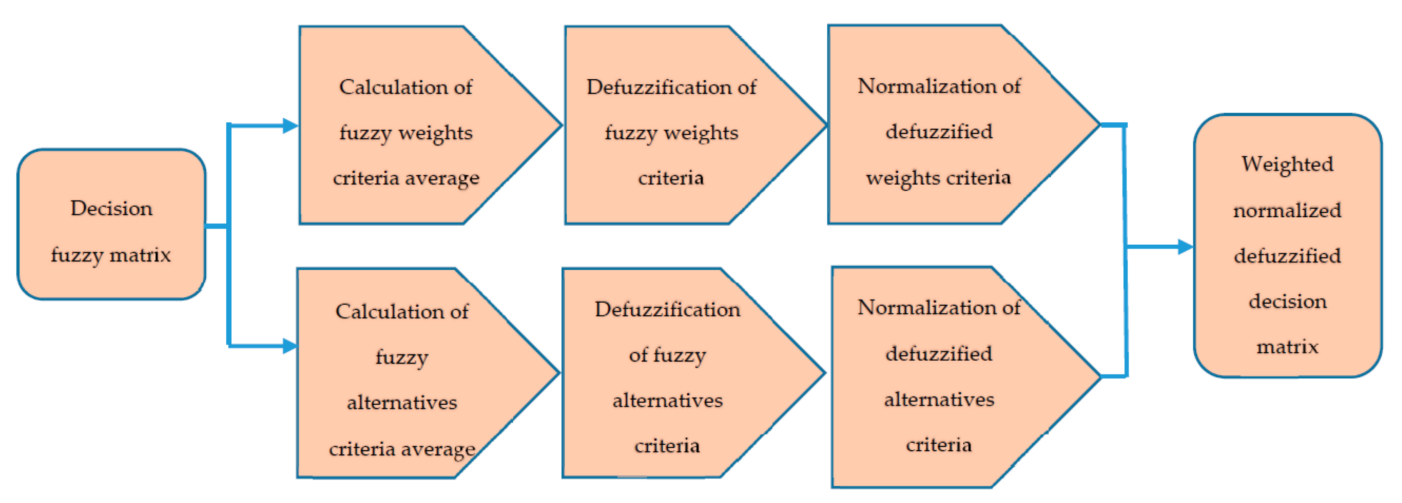

Figure 8. Weighted normalized defuzzified matrix. 
In which: $q_{j}$ is the weight of the $j$-th criterion.

During the third step, after obtaining the weighted normalized defuzzified matrix, the significance and definition of priority through calculations of the sum $P j$, sum $R i$ and optimization criterion must be obtained (Figure 9).

- Calculation of the sum $P_{j}$ : for each alternative of the fuzzified normalized and weighted values of the criteria of benefits, as they are preferable in optimization aimed at maximization

$$
P_{i}=\sum_{j=1}^{l} \hat{d}_{i j}
$$

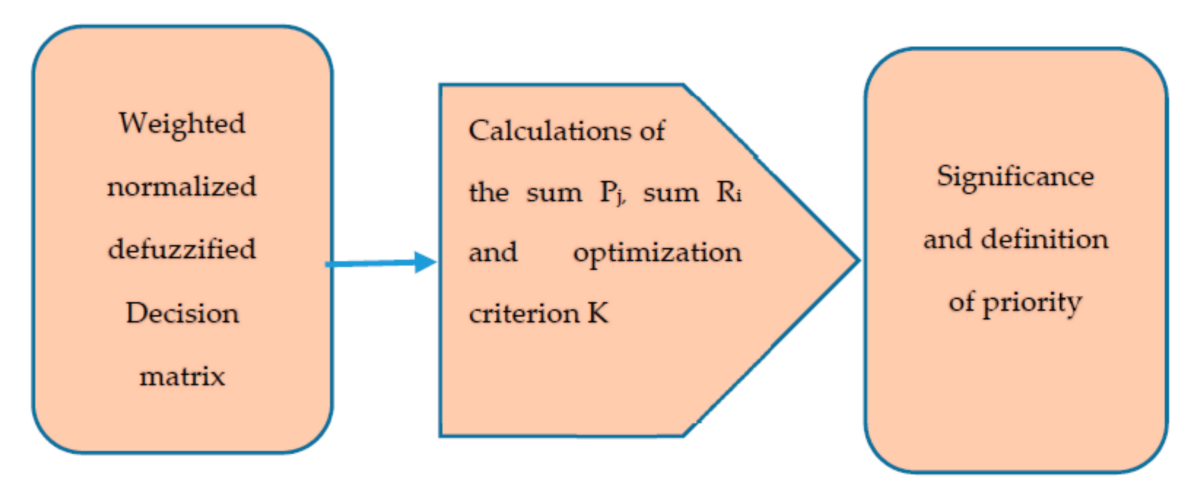

Figure 9. Significance and definition of priority.

In which: $l$ is the number of criteria that must be maximized.

- Calculation of the sum $R_{i}$ : for each alternative of the fuzzified normalized and weighted values of the criteria of costs, as they are preferable in optimization aimed at minimization:

$$
R_{i}=\sum_{j=l}^{m} \hat{d}_{i j}
$$

In which: $(m-l)$ is the number of criteria that must be minimized.

- Calculation of significance of the alternatives or relative weight of each alternative of $Q_{i}$ project:

$$
Q_{i}=P_{i}+\frac{\sum_{i=1}^{n} R_{i}}{R_{i} \sum_{i=1}^{n} \frac{1}{R_{i}}}
$$

- $\quad$ Calculation of the optimization criterion $K$, i.e., the maximum $Q_{i}(Q \max )$

- Definition of priority regarding design alternative: the greater the relative weight of the alternative $Q_{i}$, the higher the priority or significance of the design alternative. This way, the $Q_{\max }$ significance of the more rational alternative will always be that of the highest degree of satisfaction.

- Calculation of the degree of utility $N_{j}$ from $0 \%$ to $100 \%$ of the alternatives: calculated by comparing each alternative analyzed $A_{j}$ with the most efficient alternative, which has a degree of utility equal to $100 \%$, so it is possible to assess the extent to which an alternative $A_{j}$ is better or worse than the others being compared:

$$
N_{i}=\frac{Q_{i}}{Q_{\max }} 100 \%
$$

In which $Q_{i}$ and $Q_{\max }$ are the significance of the project alternatives under evaluation. As the priority of the analyzed alternative increases or decreases, its degree of utility fluctuates as well. 


\subsection{Application of the Fuzzy Complex Proportional Assessment Method}

To implement the method Complex Proportional Fuzzy Assessment (COPRAS-F) the following phases described in the items below are necessary.

\subsubsection{Research of Linguistic Classifications for Criteria Importance}

A survey for linguistic classifications of criteria importance, based on linguistic variables expressed in triangular fuzzy numbers (Table 6), was conducted with the four stakeholders from the energy utilities (D1, D2, D3 and D4), from which we reached the linguistic matrix of the importance of subcriteria weights (Appendix A).

It is important to understand that to apply the surveys, a limited number (four) decision-makers were chosen due to the requirement of extensive experience in strategic decision-making in a utility with thousands of employees, billions of dollars in revenue, and millions of consumers, occupying or having already occupied a high position in the utility.

\subsubsection{Survey of Linguistic Classifications for Alternatives}

We conducted a survey of linguistic classifications for alternatives based on linguistic variables expressed in triangular fuzzy numbers (Table 6) with the four stakeholders from the energy utilities (D1, D2, D3 and D4), from which we reached the linguistic matrix of alternative (Appendix B).

3.7.3. Fuzzified Linguistic Matrix of Weight Importance and Defuzzified by the Average with Calculation of Criteria Weight

From the results of the survey for linguistic classifications of criteria importance with the decision makers, a fuzzified linguistic matrix for the criteria was generated, later defuzzified by the mean, in which the center of area method (COA) was applied, obtaining the normalized weights (Table 7).

Table 7. Calculation of criteria weights using the center of area (COA).

\begin{tabular}{|c|c|c|c|c|c|c|c|c|c|c|c|c|c|c|c|c|c|c|}
\hline \multirow[t]{2}{*}{ Criteria } & \multirow[t]{2}{*}{$\mathbf{Z}$} & \multicolumn{12}{|c|}{ Decision Makers } & \multicolumn{3}{|c|}{ Average } & \multirow{2}{*}{$\begin{array}{c}\text { Weights } \\
\text { Defuzzified } \\
\text { (COA) }\end{array}$} & \multirow{2}{*}{$\begin{array}{c}\mathrm{q}_{\mathrm{j}} \\
\text { (Normalized } \\
\text { Weights) }\end{array}$} \\
\hline & & & D1 & & & D2 & & & D3 & & & D4 & & & & & & \\
\hline $\mathrm{C} 1$ & - & 0.9 & 1.0 & 1.0 & 0.9 & 1.0 & 1.0 & 0.7 & 0.9 & 1.0 & 0.9 & 1.0 & 1.0 & 0.850 & 0.975 & 1.000 & 0.942 & 0.117 \\
\hline $\mathrm{C} 2$ & - & 0.9 & 1.0 & 1.0 & 0.7 & 0.9 & 1.0 & 0.7 & 0.9 & 1.0 & 0.5 & 0.7 & 0.9 & 0.700 & 0.875 & 0.975 & 0.850 & 0.105 \\
\hline $\mathrm{C} 3$ & - & 0.7 & 0.9 & 1.0 & 0.5 & 0.7 & 0.9 & 0.3 & 0.5 & 0.7 & 0.7 & 0.9 & 1.0 & 0.550 & 0.750 & 0.900 & 0.733 & 0.091 \\
\hline $\mathrm{C} 4$ & - & 0.7 & 0.9 & 1.0 & 0.5 & 0.7 & 0.9 & 0.1 & 0.3 & 0.5 & 0.5 & 0.7 & 0.9 & 0.450 & 0.650 & 0.825 & 0.642 & 0.080 \\
\hline C5 & + & 0.9 & 1.0 & 1.0 & 0.9 & 1.0 & 1.0 & 0.5 & 0.7 & 0.9 & 0.9 & 1.0 & 1.0 & 0.800 & 0.925 & 0.975 & 0.900 & 0.112 \\
\hline C6 & + & 0.9 & 1.0 & 1.0 & 0.3 & 0.5 & 0.7 & 0.5 & 0.7 & 0.9 & 0.7 & 0.9 & 1.0 & 0.600 & 0.775 & 0.900 & 0.758 & 0.094 \\
\hline $\mathrm{C} 7$ & - & 0.0 & 0.0 & 0.1 & 0.0 & 0.1 & 0.3 & 0.7 & 0.9 & 1.0 & 0.3 & 0.5 & 0.7 & 0.250 & 0.375 & 0.525 & 0.383 & 0.048 \\
\hline $\mathrm{C} 8$ & - & 0.0 & 0.1 & 0.3 & 0.0 & 0.1 & 0.3 & 0.9 & 1.0 & 1.0 & 0.3 & 0.5 & 0.7 & 0.300 & 0.425 & 0.575 & 0.433 & 0.054 \\
\hline C9 & - & 0.5 & 0.7 & 0.9 & 0.5 & 0.7 & 0.9 & 0.9 & 1.0 & 1.0 & 0.5 & 0.7 & 0.9 & 0.600 & 0.775 & 0.925 & 0.767 & 0.095 \\
\hline C10 & + & 0.3 & 0.5 & 0.7 & 0.0 & 0.1 & 0.3 & 0.5 & 0.7 & 0.9 & 0.3 & 0.5 & 0.7 & 0.275 & 0.450 & 0.650 & 0.458 & 0.057 \\
\hline C11 & + & 0.3 & 0.5 & 0.7 & 0.0 & 0.1 & 0.3 & 0.5 & 0.7 & 0.9 & 0.5 & 0.7 & 0.9 & 0.325 & 0.500 & 0.700 & 0.508 & 0.063 \\
\hline C12 & + & 0.3 & 0.5 & 0.7 & 0.7 & 0.9 & 1.0 & 0.7 & 0.9 & 1.0 & 0.3 & 0.5 & 0.7 & 0.500 & 0.700 & 0.850 & 0.683 & 0.085 \\
\hline
\end{tabular}

\subsubsection{Fuzzified and Defuzzified Linguistic Matrix and Ranking Calculation}

From the linguistic matrix of alternatives (Appendix B), the fuzzified matrix was generated, later defuzzified, normalized and weighted decision matrix (Table 8). 
Table 8. Defuzzified, normalized and weighted decision matrix.

\begin{tabular}{|c|c|c|c|c|c|c|c|c|c|c|c|}
\hline \multirow[t]{3}{*}{ Criteria } & \multirow[t]{3}{*}{$\mathbf{Z}$} & \multicolumn{10}{|c|}{ Decision Makers } \\
\hline & & \multicolumn{10}{|c|}{ D1 D2 D3 D4 } \\
\hline & & A1 & A2 & A3 & A4 & A5 & A6 & A7 & A8 & A9 & A10 \\
\hline $\mathrm{C} 1$ & - & 0.004 & 0.011 & 0.020 & 0.020 & 0.011 & 0.007 & 0.004 & 0.020 & 0.011 & 0.011 \\
\hline $\mathrm{C} 2$ & - & 0.011 & 0.010 & 0.011 & 0.007 & 0.012 & 0.012 & 0.012 & 0.011 & 0.008 & 0.011 \\
\hline $\mathrm{C} 3$ & - & 0.007 & 0.009 & 0.011 & 0.011 & 0.009 & 0.007 & 0.007 & 0.011 & 0.009 & 0.009 \\
\hline $\mathrm{C} 4$ & - & 0.005 & 0.006 & 0.014 & 0.010 & 0.012 & 0.003 & 0.002 & 0.014 & 0.006 & 0.006 \\
\hline C5 & + & 0.015 & 0.012 & 0.006 & 0.006 & 0.012 & 0.014 & 0.015 & 0.006 & 0.012 & 0.012 \\
\hline C6 & + & 0.010 & 0.009 & 0.009 & 0.008 & 0.010 & 0.010 & 0.010 & 0.009 & 0.009 & 0.009 \\
\hline $\mathrm{C} 7$ & - & 0.006 & 0.001 & 0.004 & 0.004 & 0.006 & 0.008 & 0.008 & 0.005 & 0.001 & 0.004 \\
\hline $\mathrm{C} 8$ & - & 0.008 & 0.007 & 0.003 & 0.003 & 0.008 & 0.003 & 0.003 & 0.007 & 0.004 & 0.008 \\
\hline C9 & - & 0.005 & 0.009 & 0.014 & 0.014 & 0.009 & 0.007 & 0.006 & 0.014 & 0.009 & 0.009 \\
\hline C10 & + & 0.006 & 0.006 & 0.005 & 0.005 & 0.006 & 0.006 & 0.006 & 0.005 & 0.006 & 0.006 \\
\hline C11 & + & 0.007 & 0.006 & 0.006 & 0.006 & 0.006 & 0.007 & 0.007 & 0.006 & 0.006 & 0.006 \\
\hline C12 & + & 0.008 & 0.009 & 0.007 & 0.010 & 0.007 & 0.009 & 0.007 & 0.010 & 0.008 & 0.011 \\
\hline
\end{tabular}

Finally, the calculations were performed in the defuzzified, normalized and weighted matrix to determine the ranking of the alternatives of locations for the installation of photovoltaic plants (Table 9).

Table 9. Complex proportional fuzzy assessment (COPRAS-F) calculations and ranking of alternatives.

\begin{tabular}{ccccccc}
\hline Alternatives & $\begin{array}{c}\text { Pi Sum of Benefit } \\
\text { Criteria } \\
\text { (Maximization) }\end{array}$ & $\begin{array}{c}\text { Ri-Sum of } \\
\text { Cost Criteria } \\
\text { (Minimization) }\end{array}$ & 1/Ri & Qi & $\begin{array}{c}\text { Ui-Alternative } \\
\text { Priority } \\
\text { (Significance) }\end{array}$ & Ranking \\
\hline A1 & 0.05 & 0.05 & 21.81 & 0.118 & 0.956 & 2 \\
A2 & 0.04 & 0.05 & 18.96 & 0.105 & 0.846 & 5 \\
A3 & 0.03 & 0.08 & 13.06 & 0.076 & 0.619 & 10 \\
A4 & 0.04 & 0.07 & 14.48 & 0.084 & 0.678 & 8 \\
A5 & 0.04 & 0.07 & 14.95 & 0.090 & 0.732 & 7 \\
A6 & 0.05 & 0.05 & 21.05 & 0.115 & 0.934 & 3 \\
A7 & 0.05 & 0.04 & 23.69 & 0.124 & 1.000 & 1 \\
A8 & 0.04 & 0.08 & 12.10 & 0.077 & 0.625 & 9 \\
A9 & 0.04 & 0.05 & 20.66 & 0.109 & 0.882 & 4 \\
A10 & 0.04 & 0.06 & 17.37 & 0.101 & 0.819 & 6 \\
\hline
\end{tabular}

\section{Discussion of Application and Results of the Application of the MCDM COPRAS-F METHOD}

The facilities in decision making were analyzed, which became clear during the research process and the format of the results obtained by applying the COPRAS-F method (Table 9), proving the practicality of the COPRAS-F method when combining structures from:

- COPRAS: due to the direct application of benefit and cost subcriteria, in addition to calculating the degree of utility (significance) of the alternatives. This demonstrated, in percentage, to what extent an alternative is better or worse than other alternatives, which visually helps in decision making;

- FUZZY: practicality of calculating fuzzy logic in resolving conflicts between decision makers, without the need for consensus meetings.

The COPRAS-F method has demonstrated, during the stakeholders' survey process, great applicability for companies focused on energy sector projects, in which there are multiple decision-makers with different interests, and that often, when failing to reach a consensus, prefer to take more personalized decisions during meetings. 
Regarding the results of the COPRAS-F classification (Table 10), it has been observed that the alternative (A7) presented the best solution with $8.61 \mathrm{GWh} /$ year and a utility degree being $4 \%$ higher than the second-best solution (A1) with $8.47 \mathrm{GWh} /$ year, $7 \%$ higher than the third best solution (A6) and $38 \%$ higher in relation to the worst solution (A3). The technical priority of power generation in relation to the other business criteria is evident.

Table 10. MCDM COPRAS-F ranking.

\begin{tabular}{ccccccccccc}
\hline Variables & \multicolumn{10}{c}{ Alternatives } \\
\hline & A1 & A2 & A3 & A4 & A5 & A6 & A7 & A8 & A9 & A10 \\
\hline Priority & 0.96 & 0.85 & 0.62 & 0.68 & 0.73 & 0.93 & 1.00 & 0.63 & 0.88 & 0.82 \\
Ranking COPRAS-F & 2 & 5 & 10 & 8 & 7 & 3 & 1 & 9 & 4 & 6 \\
\hline
\end{tabular}

\section{Conclusions}

This section covers the decision-making model proposed here, and suggested improvements for future models.

\subsection{Analysis and Discussion of the Proposed Decision-Making Model}

Aiming at this advance in relation to current methods, the Fuzzy COPRAS method was applied in this article with business criteria in alternatives of sites identified from a geographic suitability index map of Southern Brazil, thus establishing a ranking among alternative areas with the best geographic characteristics of 10 mesoregions (Table 10).

The differences observed between the GIS-MCDM ranking, established by the geographic suitability index, and the ranking obtained when applying COPRAS-F (Table 11), demonstrate the need for integrating both the geographic and business points of view.

The best locations from the geographic point of view for the installation of photovoltaic plants were ranked based on the geographic suitability index, which was obtained through the GIS-MCDM, and they were not the best locations from the business point of view, as ranked by MCDM Fuzzy COPRAS method (Table 11). This occurs especially in the case of large territorial extensions that present heterogeneity in economic, social, and environmental aspects.

Table 11. GIS-MCDM and COPRAS-F ranking.

\begin{tabular}{ccccccccccc}
\hline Method & \multicolumn{1}{c}{ Alternatives } \\
\hline & A1 & A2 & A3 & A4 & A5 & A6 & A7 & A8 & A9 & A10 \\
\hline $\begin{array}{c}\text { Geographic } \\
\text { Suitability Index }\end{array}$ & 0.91 & 0.85 & 0.86 & 0.75 & 0.95 & 0.94 & 0.93 & 0.9 & 0.83 & 0.89 \\
Ranking GIS & 4 & 8 & 7 & 10 & 1 & 2 & 3 & 5 & 9 & 6 \\
\hline Priority & 0.96 & 0.85 & 0.62 & 0.68 & 0.73 & 0.93 & 1.00 & 0.63 & 0.88 & 0.82 \\
Ranking COPRAS-F & 2 & 5 & 10 & 8 & 7 & 3 & 1 & 9 & 4 & 6 \\
\hline
\end{tabular}

The contributions of the proposed model for the location of areas in vast and heterogeneous extensions of land for the installation of photovoltaic plants are:

- Eliminate the weaknesses of the GIS and GIS-MCDM models in the impossibility of mapping business subcriteria, and the weaknesses of the MCDM method in the impossibility of mapping geographical subcriteria;

- Demonstrate the complementarity between geographical subcriteria, which can be excellent in the selection of geographically suitable areas, and business subcriteria, which can be excellent for the classification of site alternatives regarding the viability of an enterprise. 
On the other hand, the application of the present model has not been shown to make sense in selecting and classifying alternative areas for installation of photovoltaic plants in:

- Regions characterized by economic, social, and environmental homogeneity, in which case the direct use of the GIS or GIS-MCDM methods prevails;

- Regions characterized by climatic, geomorphological, location and land use homogeneity, in which case the direct use of MCDM methods prevails.

\subsection{Analysis and Discussion of Future Decision-Making Models}

Here are some suggestions for the next steps in improving this MCDM model:

- Develop research involving structuring criteria for localization applications for distributed renewable energies, primarily wind energy, wind-photovoltaic and hydraulic hybrids aimed at small hydroelectric plants;

- Apply other MCDM or MCDM-FUZZY methods with new business sub-criteria determined by business literature or policies or consensus of decision makers [36,39-42], such as: political and economic instability, changes in policy changes in policy premiums, financing policy, environmental releases.

Author Contributions: Conceptualization, P.A.X.F. and A.V.H.S.; methodology, P.A.X.F.; software, P.A.X.F.; validation, P.A.X.F.; formal analysis, P.A.X.F. and A.V.H.S.; investigation, P.A.X.F.; resources, P.A.X.F.; data curation, P.A.X.F.; writing—original draft preparation, P.A.X.F. and A.V.H.S.; writing—review and editing, P.A.X.F. and A.V.H.S.; visualization, P.A.X.F.; supervision, A.V.H.S.; project administration, A.V.H.S. All authors have read and agreed to the published version of the manuscript.

Funding: This research was financed in part by CAPES.

Acknowledgments: This work was financed in part by CAPES (project PROCAD 071/2013), an institution linked to the Brazilian Ministry of Education, to which the authors are grateful. The authors also thank the following institutions that supported the project: Federal University of Technology-Paraná, Federal University of Pernambuco, Federal University of Paraná, and the Electric Power Company in Brazil.

Conflicts of Interest: The authors declare that there are no conflict of interest.

\section{Nomenclature}

$\begin{array}{ll}\text { COPRAS-F } & \text { Fuzzy Complex Proportional Assessment } \\ \text { MCDM } & \text { Multi-Criteria Decision-Making } \\ \text { GIS } & \text { Geographic Information Systems } \\ \text { WLC } & \text { Weighted Linear Combination } \\ \text { OWA } & \text { Ordered Weighted Average } \\ \text { FLOWA } & \text { Ordered Weighted Average Fuzzy } \\ \text { AHP } & \text { Analytic Hierarchy Process } \\ \text { SWARA } & \text { Step-Wise Weight Assessment Ratio Analysis } \\ \text { WASPAS } & \text { Weighted Aggregates Sum Product Assessment } \\ \text { CODAS } & \text { Applied the Combinative Distance Based Assessment } \\ \text { TOPSIS } & \text { Technique for Order of Preference by Similarity to Ideal Solution } \\ \text { F-PROMETHEE Evaluation } & \text { Fuzzy Preference Ranking Organization METHod Enrichment }\end{array}$

\section{Appendix A. Linguistic Matrix of Importance of Criteria Weights}

It follows the linguistic matrix of the importance of subcriteria weights (Table A1) obtained in a survey carried out with stakeholders, applying linguistic terms associated with the subcriteria. 
Table A1. Linguistic matrix of importance of subcriteria weights.

\begin{tabular}{cccccc}
\hline Criteria i & Z Cost (-)/Benefits (+) & \multicolumn{3}{c}{ Decision Makers } & \\
\hline & & D1 & D2 & D3 & D4 \\
\hline C1 & - & VH & VH & H & VH \\
C2 & - & VH & H & H & MH \\
C3 & - & H & MH & M & H \\
C4 & - & H & MH & ML & MH \\
C5 & + & VH & VH & MH & VH \\
C6 & + & VH & M & MH & H \\
C7 & - & VL & L & H & M \\
C8 & - & L & L & VH & M \\
C9 & - & MH & MH & VH & MH \\
C10 & + & M & L & MH & M \\
C11 & + & M & L & MH & MH \\
C12 & + & M & H & H & M \\
\hline
\end{tabular}

\section{Appendix B. Linguistic Matrix of Alternatives A1-A2-A3-A4-A5-A6-A7-A8-A9-A10}

It follows the linguistic matrix of alternatives (Tables A2-A4) obtained in a survey carried out with stakeholders, applying linguistic terms associated with the alternatives.

Table A2. Linguistic matrix of alternatives A1-A2-A3-A4.

\begin{tabular}{|c|c|c|c|c|c|c|c|c|c|c|c|c|c|c|c|c|c|}
\hline \multirow[t]{3}{*}{ Criteria } & \multirow[t]{3}{*}{$\mathrm{Z}$} & \multicolumn{16}{|c|}{ Decision Makers } \\
\hline & & \multicolumn{4}{|c|}{ D1 } & \multicolumn{4}{|c|}{ D2 } & \multicolumn{4}{|c|}{ D3 } & \multicolumn{4}{|c|}{ D4 } \\
\hline & & A1 & A2 & A3 & A4 & A1 & A2 & A3 & A4 & A1 & A2 & A3 & A4 & A1 & A2 & A3 & A4 \\
\hline $\mathrm{C} 1$ & - & $\mathrm{VP}$ & $\mathrm{M}$ & VG & VG & $\mathrm{MP}$ & MG & VG & VG & $\mathrm{MP}$ & $\mathrm{M}$ & G & G & $\mathrm{VP}$ & $\mathrm{MP}$ & VG & VG \\
\hline $\mathrm{C} 2$ & - & G & MG & MG & $\mathrm{M}$ & MG & MG & MG & $\mathrm{MP}$ & $\mathrm{M}$ & $\mathrm{MP}$ & $\mathrm{M}$ & $\mathrm{MP}$ & MG & MG & MG & M \\
\hline $\mathrm{C} 3$ & - & $\mathrm{M}$ & MG & VG & VG & $\mathrm{M}$ & MG & G & G & $\mathrm{MP}$ & $\mathrm{MP}$ & $\mathrm{MP}$ & $\mathrm{MP}$ & MG & G & VG & VG \\
\hline $\mathrm{C} 4$ & - & $\mathrm{MP}$ & $\mathrm{MP}$ & G & $\mathrm{M}$ & $\mathrm{M}$ & MG & G & MG & $\mathrm{VP}$ & $\mathrm{VP}$ & $\mathrm{P}$ & $\mathrm{P}$ & $\mathrm{P}$ & $\mathrm{MP}$ & VG & MG \\
\hline C5 & + & $\mathrm{G}$ & MG & $\mathrm{MP}$ & $\mathrm{MP}$ & VG & MG & $\mathrm{MP}$ & $\mathrm{MP}$ & MG & $\mathrm{M}$ & $\mathrm{MP}$ & $\mathrm{MP}$ & VG & G & $\mathrm{M}$ & $\mathrm{M}$ \\
\hline C6 & + & MG & MG & MG & $\mathrm{M}$ & G & MG & MG & $\mathrm{M}$ & MG & MG & MG & MG & MG & MG & MG & MG \\
\hline $\mathrm{C} 7$ & - & $\mathrm{M}$ & VP & $\mathrm{P}$ & $\mathrm{P}$ & $\mathrm{G}$ & $\mathrm{VP}$ & $\mathrm{M}$ & $\mathrm{M}$ & $\mathrm{MP}$ & VP & $\mathrm{MP}$ & $\mathrm{MP}$ & MG & MP & $\mathrm{M}$ & $\mathrm{M}$ \\
\hline C8 & - & $\mathrm{G}$ & MG & $\mathrm{MP}$ & $\mathrm{M}$ & VG & MG & VP & VP & $\mathrm{M}$ & $\mathrm{M}$ & VP & $\mathrm{VP}$ & VG & VG & $\mathrm{G}$ & G \\
\hline C9 & - & $\mathrm{VP}$ & $\mathrm{MP}$ & $\mathrm{G}$ & $\mathrm{G}$ & $\mathrm{MP}$ & $\mathrm{MG}$ & VG & VG & $\mathrm{MP}$ & $\mathrm{MP}$ & $\mathrm{M}$ & $\mathrm{M}$ & $\mathrm{M}$ & $\mathrm{MG}$ & VG & VG \\
\hline C10 & + & VG & $\mathrm{G}$ & MG & MG & $\mathrm{G}$ & MG & $\mathrm{MG}$ & MG & $\mathrm{M}$ & $\mathrm{M}$ & $\mathrm{M}$ & $\mathrm{M}$ & $\mathrm{M}$ & $\mathrm{M}$ & $\mathrm{M}$ & $\mathrm{M}$ \\
\hline C11 & + & VG & MG & MG & MG & G & MG & $\mathrm{MG}$ & MG & $\mathrm{MG}$ & MG & $\mathrm{MG}$ & MG & MG & $\mathrm{MG}$ & MG & MG \\
\hline C12 & + & MG & $\mathrm{G}$ & MG & VG & $\mathrm{M}$ & $\mathrm{MG}$ & $\mathrm{MP}$ & $\mathrm{G}$ & $\mathrm{M}$ & $\mathrm{M}$ & $\mathrm{M}$ & MG & G & G & $\mathrm{MG}$ & VG \\
\hline
\end{tabular}

Table A3. Linguistic matrix of alternatives A5-A6-A7-A8.

\begin{tabular}{|c|c|c|c|c|c|c|c|c|c|c|c|c|c|c|c|c|c|}
\hline \multirow[t]{3}{*}{ Criteria } & \multirow[t]{3}{*}{$\mathrm{Z}$} & \multicolumn{16}{|c|}{ Decision Makers } \\
\hline & & \multicolumn{4}{|c|}{ D1 } & \multicolumn{4}{|c|}{ D2 } & \multicolumn{4}{|c|}{ D3 } & \multicolumn{4}{|c|}{ D4 } \\
\hline & & A5 & A6 & A7 & A8 & A5 & A6 & A7 & A8 & A5 & A6 & A7 & A8 & A5 & A6 & A7 & A8 \\
\hline $\mathrm{C} 1$ & - & $\mathrm{M}$ & $\mathrm{MP}$ & $\mathrm{VP}$ & VG & MG & M & MP & VG & $\mathrm{M}$ & $\mathrm{MP}$ & $\mathrm{MP}$ & G & $\mathrm{MP}$ & $\mathrm{P}$ & $\mathrm{VP}$ & VG \\
\hline $\mathrm{C} 2$ & - & G & $\mathrm{G}$ & G & $\mathrm{G}$ & G & G & G & MG & $\mathrm{M}$ & $\mathrm{M}$ & $\mathrm{M}$ & $\mathrm{M}$ & MG & MG & MG & MG \\
\hline $\mathrm{C} 3$ & - & MG & M & $\mathrm{M}$ & VG & MG & M & M & G & $\mathrm{MP}$ & $\mathrm{MP}$ & $\mathrm{MP}$ & $\mathrm{MP}$ & G & MG & MG & VG \\
\hline $\mathrm{C} 4$ & - & MG & $\mathrm{P}$ & $\mathrm{VP}$ & $\mathrm{G}$ & G & M & $\mathrm{MP}$ & VG & $\mathrm{P}$ & $\mathrm{VP}$ & $\mathrm{VP}$ & $\mathrm{P}$ & G & $\mathrm{VP}$ & $\mathrm{P}$ & VG \\
\hline C5 & + & MG & G & $\mathrm{G}$ & $\mathrm{MP}$ & MG & G & VG & $\mathrm{MP}$ & $\mathrm{M}$ & MG & MG & $\mathrm{MP}$ & G & $\mathrm{G}$ & VG & $\mathrm{M}$ \\
\hline C6 & + & MG & MG & MG & MG & VG & VG & VG & MG & MG & MG & MG & MG & $\mathrm{MG}$ & $\mathrm{MG}$ & MG & MG \\
\hline C7 & - & $\mathrm{M}$ & MG & MG & MP & G & VG & VG & MG & $\mathrm{MP}$ & $\mathrm{M}$ & $\mathrm{M}$ & $\mathrm{MP}$ & MG & VG & VG & $\mathrm{M}$ \\
\hline C8 & - & $\mathrm{G}$ & $\mathrm{MP}$ & $\mathrm{MP}$ & MG & G & VP & $\mathrm{VP}$ & MG & $\mathrm{M}$ & $\mathrm{VP}$ & VP & $\mathrm{M}$ & VG & $\mathrm{G}$ & $\mathrm{G}$ & VG \\
\hline C9 & - & $\mathrm{MP}$ & $\mathrm{P}$ & $\mathrm{VP}$ & $\mathrm{G}$ & MG & $\mathrm{M}$ & $\mathrm{MP}$ & VG & $\mathrm{MP}$ & $\mathrm{MP}$ & $\mathrm{MP}$ & $\mathrm{M}$ & MG & $\mathrm{MG}$ & $\mathrm{MG}$ & VG \\
\hline C10 & + & $\mathrm{G}$ & $\mathrm{G}$ & VG & MG & MG & MG & G & MG & $\mathrm{M}$ & $\mathrm{M}$ & $\mathrm{M}$ & $\mathrm{M}$ & $\mathrm{M}$ & $\mathrm{M}$ & $\mathrm{M}$ & $\mathrm{M}$ \\
\hline C11 & + & MG & G & VG & MG & MG & G & G & MG & MG & MG & MG & MG & MG & MG & $\mathrm{MG}$ & MG \\
\hline $\mathrm{C} 12$ & + & $\mathrm{M}$ & G & $\mathrm{MG}$ & VG & $\mathrm{M}$ & MG & $\mathrm{MP}$ & $\mathrm{G}$ & $\mathrm{M}$ & $\mathrm{M}$ & $\mathrm{M}$ & $\mathrm{MG}$ & G & G & $\mathrm{MG}$ & VG \\
\hline
\end{tabular}


Table A4. Linguistic matrix of alternatives A9-A10.

\begin{tabular}{cccccccccc}
\hline Criteria & Z & \multicolumn{9}{c}{ Decision Makers } \\
\hline & & \multicolumn{2}{c}{ D1 } & \multicolumn{2}{c}{ D2 } & \multicolumn{2}{c}{ D3 } & \multicolumn{2}{c}{ D4 } \\
\hline & & A9 & A10 & A9 & A10 & A9 & A10 & A9 & A10 \\
\hline C1 & - & M & M & MG & MG & M & M & MP & MP \\
C2 & - & M & MG & M & MG & MP & M & MG & MG \\
C3 & - & MG & MG & MG & MG & MP & MP & G & G \\
C4 & - & MP & MP & MG & MG & VP & VP & MP & MP \\
C5 & + & MG & MG & MG & MG & M & M & G & G \\
C6 & + & MG & MG & MG & MG & MG & MG & MG & MG \\
C7 & - & VP & P & P & M & VP & MP & MP & M \\
C8 & - & M & VG & P & VG & VP & M & VG & VG \\
C9 & - & MP & MP & MG & MG & MP & MP & MG & MG \\
C10 & + & G & G & MG & MG & M & M & M & M \\
C11 & + & MG & MG & MG & MG & MG & MG & MG & MG \\
C12 & + & MG & VG & M & VG & M & MG & G & VG \\
\hline
\end{tabular}

\section{References}

1. Jemai, K. Intelligent integration strategies of wind farms in a super grid. J. Intell. Fuzzy Syst. 2016, 31, 275-290. [CrossRef]

2. Bhuvanesha, A.; Christab, S.T.J.; Kannanc, S.; Pandiyand, M.K.; Gangatharane, K. Application of optimization algorithms to generation expansion planning problem. J. Intell. Fuzzy Syst. 2018, 35, 1387-1398. [CrossRef]

3. Castillo, C.P.; Silva, F.B.; Lavalle, C. An assessment of the regional potential for solar power generation in EU-28. Energy Policy 2016, 88, 86-99. [CrossRef]

4. Tomosk, S.; Haysom, J.E.; Hinzer, K.; Schriemer, H.; Wrig, D. Mapping the geographic distribution of the economic viability of PV load displacement projects in SW USA. Renew Energy 2017, 107, 101-112. [CrossRef]

5. Vafaeipour, M.; Zolfani, S.H.; Varzandeh, M.H.M.; Derakhti, A.; Eshkalag, M.K. Assessment of regions priority for implementation of solar projects in Iran: New application of a hybrid multi-criteria decision making approach. Energy Convers. Manag. 2014, 86, 653-663. [CrossRef]

6. Brewer, J.; Ames, D.P.; Solan, D.; Lee, R.; Carlisle, J. Using GIS analytics and social preference data to evaluate utility-scale solar power site suitability. Renew. Energy Rev. 2015, 81, 825-836. [CrossRef]

7. Janke, J.R. Multicriteria GIS modeling of wind and solar farms in Colorado. Renew. Energy Rev. 2010, 35, 2228-2234. [CrossRef]

8. Sabo, M.L.; Mariun, N.; Hizam, H.; Radzi, M.A.M.; Zakaria, A. Spatial energy predictions from large-scale photovoltaic power plants located in optimal sites and connected to a smart grid in Peninsular Malaysia. Renew. Sustain. Energy Rev. 2016, 66, 79-94. [CrossRef]

9. Wang, S.; Zhang, L.; Fu, D.; Lu, X.; Wu, T.; Tong, Q. Selecting photovoltaic generation sites in Tibet using remote sensing and geographic analysis. Sol. Energy 2016, 133, 85-93. [CrossRef]

10. Maleki, A.; Pourfayaz, F.; Hafeznia, H.; Rosen, M.A. A novel framework for optimal photovoltaic size and location in remote areas using a hybrid method: A case study of eastern Iran. Energy Convers. Manag. 2017, 153, 129-143. [CrossRef]

11. Charabi, Y.; Gastli, A. PV site suitability analysis using GIS-based spatial fuzzy multi-criteria evaluation. Renew. Energy 2011, 36, 2554-2561. [CrossRef]

12. Al Garni, H.Z.; Awasthi, A. Solar PV power plant site selection using a GIS-AHP based approach with application in Saudi Arabia. Appl. Energy 2017, 206, 1225-1240. [CrossRef]

13. Aydin, N.Y.; Kentel, E.; Duzgun, H.S. GIS-based site selection methodology for hybrid renewable energy systems: A case study from western Turkey. Energy Convers. Manag. 2013, 70, 90-106. [CrossRef]

14. Wanderer, T.; Herle, S. Creating a spatial multi-criteria decision support system for energy related integrated environmental impact assessment. Environ. Impact Assess. Rev. 2015, 52, 2-8. [CrossRef]

15. Watson, J.J.W.; Hudson, M.D. Regional Scale wind farm and solar farm suitability assessment using GIS-assisted multi-criteria evaluation. Landsc. Urban Plan. 2015, 138, 20-31. [CrossRef] 
16. Merrouni, A.A.; Elalaoui, F.E.; Mezrhab, A.; Mezrhab, A.; Ghennioui, A. Large scale PV sites selection by combining GIS and Analytical Hierarchy Process. Case study: Eastern Morocco. Renew. Energy 2018, 119, 863-873. [CrossRef]

17. Mourmouris, J.C.; Potolias, C. A multi-criteria methodology for energy planning and developing renewable energy sources at a regional level: A case study Thassos. Greece Energy Policy 2013, 52, 522-530. [CrossRef]

18. Wang, C.N.; Nguyen, V.T.; Thai, H.T.N.; Duong, D.H. Multi-Criteria Decision Making (MCDM) Approaches for Solar Power Plant Location Selection in Vietnam. Energies 2018, 11, 1504. [CrossRef]

19. Barin, A.; Canha, L.N.; Abaide, A.R.; Magnago, K.F.; Matos, M.A.; Orling, R.B. A novel fuzzy-based expert system for RET selection. J. Intell. Fuzzy Syst. 2013, 25, 325-333. [CrossRef]

20. Karasan, A.; Bolturk, E.; Kahraman, C. A novel neutrosophic CODAS method: Selection among wind energy plant locations. J. Intell. Fuzzy Syst. 2019, 36, 1491-1504. [CrossRef]

21. Samanlioglu, F.; Ayag, Z. A fuzzy AHP-PROMETHEE II approach for evaluation of solar power plant location alternatives in Turkey. J. Intell. Fuzzy Syst. 2017, 33, 859-871. [CrossRef]

22. Zerpa, J.C.R.; Yusta, J.M. Application of multicriteria decision methods for electric supply planning in rural and remote areas. Renew. Sustain. Energy Rev. 2015, 52, 557-571. [CrossRef]

23. Dorfeshan, Y.; Mousavi, S.M. A group TOPSIS-COPRAS methodology with Pythagorean fuzzy sets considering weights of experts for project critical path problem. J. Intell. Fuzzy Syst. 2019, 36, 1375-1387. [CrossRef]

24. Beltrán, P.A.; González, F.C.; Pascual, J.; Ferrando, P.; Rubio, A.P. An AHP (Analytic Hierarchy Process)/ANP (Analytic Network Process)-based multi-criteria decision approach for the selection of solar-thermal power plant investment projects. Energy 2014, 66, 222-238. [CrossRef]

25. Haddad, B.; Liazid, A.; Ferreira, P. A multi-criteria approach to rank renewables for the Algerian electricity system. Renew. Energy 2017, 107, 462-472. [CrossRef]

26. Klein, S.J.W.; Whalley, S. Comparing the sustainability of U.S. electricity options through multi-criteria decision analysis. Energy Policy 2015, 79, 127-149. [CrossRef]

27. La Rovere, E.L.; Soares, J.B.; Oliveira, L.B.; Lauria, T. Sustainable expansion of electricity sector: Sustainability indicators as an instrument to support decision making. Renew. Sustain. Energy Rev. 2010, 14, 422-429. [CrossRef]

28. Stein, E.W. A comprehensive multi-criteria model to rank electric energy production Technologies. Renew. Sustain. Energy Rev. 2013, 22, 640-654. [CrossRef]

29. Tsoutsos, T.; Drandaki, M.; Frantzeskaki, N.; Iosifidis, E.; Kiosses, I. Sustainable energy planning by using multi-criteria analysis application in the island of Crete. Energy Policy 2009, 37, 1587-1600. [CrossRef]

30. Wang, J.J.; Jing, Y.Y.; Zhang, C.F.; Zhao, J.H. Review on multi-criteria decision analysis aid in sustainable energy decision-making. Renew. Sustain. Energy Rev. 2009, 13, 2263-2278. [CrossRef]

31. Maxim, A. Sustainability assessment of electricity generation technologies using weighted multi-criteria decision analysis. Energy Policy 2014, 65, 284-297. [CrossRef]

32. Grossmann, W.D.; Grossmann, I.; Steininger, K.W. Solar electricity generation across large geographic areas, Part II: A Pan-American energy system based on solar. Renew. Sustain. Energy Rev. 2014, 32, 983-993. [CrossRef]

33. Onat, N.; Bayar, H. The sustainability indicators of power production systems. Renew. Sustain. Energy Rev. 2010, 14, 3108-3115. [CrossRef]

34. Zhang, L.; Zhou, P.; Newton, S.; Fang, J.X.; Zhou, D.; Zhang, L. Evaluating clean energy alternatives for Jiangsu, China: An improved multi-criteria decision making method. Energy 2015, 90, 953-964. [CrossRef]

35. Chatterjee, N.C.; Bose, G.K. A COPRAS-F base multi-criteria group decision making approach for site selection of wind farm. Decis. Sci. Lett. 2012, 2, 1-10. [CrossRef]

36. Nezhad, M.R.G.; Zolfani, S.H.; Moztarzadeh, F.; Zavadskas, E.K.; Bahrami, M. Planning the priority of high tech industries based on SWARA-WASPAS methodology. The case of the nanotechnology industry in Iran. Econ. Res. 2015, 28, 1111-1137. [CrossRef]

37. Yazdani, M.; Alidoosti, A.; Zavadskas, E.K. Risk Analysis of Critical Infrastructures Using Fuzzy Copras. Econ. Res. Ekon. Istraživanja 2011, 24, 27-40. [CrossRef]

38. Mulliner, E.; Malys, N.; Maliene, V. Comparative analysis of MCDM methods for the assessment of sustainable housing affordability. Omega 2016, 59, 146-156. [CrossRef] 
39. Zoghi, M.; Ehsani, A.H.; Sadat, M.; Amiri, M.J.; Karimi, S. Optimization solar site selection by fuzzy logic model and weighted linear combination method in arid and semi-arid region: A case study Isfahan-IRAN. Renew. Sustain. Energy Rev. 2017, 68, 986-996. [CrossRef]

40. Juodagalviené, B.; Turskis, Z.; Šaparauskas, J.; Endriukaityté, A. Integrated Multi-Criteria Evaluation House's Plan Shape based on the EDAS and SWARA Methods. Eng. Struct. Technol. 2017, 9, 117-125. [CrossRef]

41. Mardani, A.; Nilashi, M.; Zakuan, N.; Loganathan, N.; Soheilirad Saman, M.Z.M.; Ibrahim, O. A systematic review and meta-Analysis of SWARA and WASPAS methods: Theory and applications with recent fuzzy developments. Appl. Soft Comput. 2017, 57, 265-292. [CrossRef]

42. Panahi, S.; Khakzad, A.; Afzal, P. Application of stepwise weight assessment ratio analysis (SWARA) for copper prospectivity mapping in the Anarak region, central Iran. Arab. J. Geosci. 2017, 10, 484. [CrossRef]

Publisher's Note: MDPI stays neutral with regard to jurisdictional claims in published maps and institutional affiliations.

(C) 2020 by the authors. Licensee MDPI, Basel, Switzerland. This article is an open access article distributed under the terms and conditions of the Creative Commons Attribution (CC BY) license (http://creativecommons.org/licenses/by/4.0/). 